\title{
Pembuatan Pestisida Nabati Pada Kelompok Tani Wanita Sejahtera di Desa Sikapat
}

\author{
Ratna Dwi Hirma Windriyati*1, Larin Tikafebianti², Gita Anggraeni ${ }^{3}$ \\ 1,2,3 Program Studi Agroteknologi, Fakultas Sains dan Teknologi, Universitas Nahdlatul Ulama Purwokerto \\ *e-mail: rdh.windriyati@gmail.com
}

\begin{abstract}
The Women Farmer Group Sejahtera mostly housewives or decorative plant farmer in Sikapat villages, Sumbang district, Banyumas regency. Its located in northern city of Purwokerto, within 15,2 km from UNU Purwokerto. Its location in highland (800 masl) has good potential for horticultural and ornamentalplant cultivation. One obstacle of farmer group is presence of pest and pathogen. Control usually done by farmer with spraying sinthetic pesticides. This PKM provides another alternative, used botanical pesticides that more environmentally friendly, through training make botanical pesticides. The methode used was counseling, training and application. The result of PKM was an increase knowledge and skills about the benefits and ways of making botanical pesticides from plants around the house. Botanical pesticides can reduce production costs and potentially as a home industry.
\end{abstract}

Keywords: botanical pesticides, women farmer group sejahtera

\begin{abstract}
Abstrak
Kelompok Tani Wanita Sejahtera sebagian besar merupakan ibu rumah tangga atau petani tanaman hias di Desa Sikapat, Kecamatan Sumbang, Kabupaten Banyumas. Terletak di sebelah utara kota Purwokerto, dengan jarak $15.2 \mathrm{~km}$ dari kampus UNU Purwokerto. Letaknya yang berada di dataran tinggi (800 mdpl) memiliki potensi yang baik untuk budidaya tanaman hortikultura dan tanaman hias. Salah satu kendala yang sering dihadapi oleh kelompok tani yaitu adanya organisme pengganggu tanaman (OPT). Pengendalian yang biasa dilakukan petani hingga saat ini dengan penyemprotan menggunakan pestisida sintetik yang di jual di pasaran. PKM ini memberikan alternatif lain yaitu penggunaan pestisida nabati yang lebih ramah lingkungan, dengan pelatihan pembuatan pestisida nabati. Metode yang dilakukan yaitu penyuluhan, pelatihan dan aplikasi. Hasil dari pengabdian ini adalah peningkatan pengetahuan dan keterampilan tentang manfaat dan cara pembuatan pestisida nabati dari tanaman di sekitar rumah. Pestisida nabati yang dibuat sendiri dapat mengurangi biaya produksi dan berpotensi sebagai industri rumah tangga.
\end{abstract}

Kata kunci: pestisida nabati, kelompok tani wanita sejahtera

\section{PENDAHULUAN}

Kelompok Tani Sejahtera merupakan kelompok tani wanita yang ada di Desa Sikapat, Kecamatan Sumbang, Kabupaten Banyumas, yang sebagian besar merupakan ibu rumah tangga atau petani tanaman hias. Desa Sikapat merupakan salah satu desa yang masuk dalam Kecamatan Sumbang, Kabupaten Banyumas. Letak geografis desa Sikapat berada sekitar 800 mdpl, sehingga termasuk kawasan dataran tinggi. Desa Sikapat terletak di sebelah utara kota Purwokerto, dengan jarak 15.2 km dari kampus UNU Purwokerto. Desa Sikapat memiliki potensi berupa lahan yang luas untuk budidaya tanaman baik tanaman pangan, hortikultura maupun tanaman hias. Salah satu kendala yang sering dihadapi oleh kelompok tani wanita Sejahtera di desa Sikapat yaitu adanya organisme pengganggu tanaman (OPT), baik hama maupun patogen. Kerugian yang dialami petani biasanya berupa kerusakan tanaman, baik kualitas maupun kuantitas. Upaya pengendalian yang telah dilakukan hingga saat ini yaitu dengan penyemprotan pestisida sintetik yang biasa dijual di pasaran.

Penggunaan pestisida sudah tidak asing lagi bagi petani, namun penggunaan pestisida sintetik yang melebihi dosis dan terus menerus tidak dianjurkan karena dapat menimbulkan dampak negatif seperti meningkatkan resistensi hama, munculnya hama baru, terbunuhnya 
musuh alami, penumpukan residu kimia pada hasil panen dan pencemaran lingkungan (Arif, 2015). Penggunaan pestisida sintetik dalam jangka panjang juga dapat menggangu kesehatan manusia karena adanya kandungan zat kimia yang bersifat karsinogenik. Salah satu dampak penggunaan pestisida yaitu mengakibatkan menurunnya tingkat kekebalan tubuh (Corsini et al., 2013). Selain itu juga dapat mengakibatkan berbagai penyakit lain seperti kanker, Parkinson dan beberapa kelainan lain (Gilden et al., 2010). Oleh karena itu penggunaan pestisida nabati yang ramah lingkungan lebih disarankan daripada penggunaan pestisida sintetik. Pestisida nabati merupakan pestisida yang terbuat dari bahan tanaman. Bahan yang digunakan bersifat alami sehingga aman digunakan. Residu yang ditinggalkan pun lebih mudah dihilangkan sehingga tidak berbahaya bagi manusia maupun lingkungan. Beberapa jenis tanaman yang diketahui mempunyai potensi sebagai pestisida diantaranya adalah daun sirsak, daun pepaya, bawang putih dan tembakau. Pestisida nabati dapat dibuat dengan cara yang sederhana sehingga mudah dibuat dan dengan harganya yang relatif lebih murah.

Menurut Lebang et al. (2016), ekstrak daun sirsak pada konsentrasi 5\% dapat menekan hama walang sangit dengan tingkat kematian 55\%, sedangkan pada konsentrasi 15\% dan 20\% dapat menekan kematian walang sangit hingga 65\% dan 83\%. Semakin tinggi konsentrasi maka semakin besar pengaruhnya terhadap kematian hama. Hal ini serupa dengan penelitian Hartini dan Yahdi (2015), semakin tinggi konsentrasi ektrak daun sirsak semakin tinggi tingkat kematian kutu daun (Myzus persicae) pada tanaman cabai, bahkan pada konsentrasi 10\% mortalitasnya mencapai $100 \%$. Daun sirsak mengandung senyawa flavonoid, saponin dan steroid yang bersifat racun perut pada konsentrasi yang tinggi, sehingga menyebabkan kematian hama.

Ekstrak daun pepaya 5\% dapat memperlambat munculnya gejala penyakit antraknosa pada buah cabai yang disebabkan jamur Colletotrichum sp. (Yulianty et al., 2018). Selain itu juga dapat menekan serangan kutu daun Aphis gossypii pada tanaman terung. Ekstrak daun pepaya konsentrasi $10 \%$ dapat menekan kutu daun hingga mortalitas $76 \%$, dan semakin tinggi konsentrasi ektrak pepaya maka semakin tinggi pula tingkat mortalitas kutu daun (Romadhona et al., 2018). Ekstrak daun pepaya mengandung senyawa papain dapat menganggu aktifitas makan dan metabolisme hama sehingga kekurangan nutrisi dan mati.

Bawang putih dan tembakau dapat dimanfaatkan sebagai pestisida secara kombinasi maupun tunggal. Keduanya mempunyai efektivitas yang berbeda namun sama-sama dapat menekan hama kutu daun pada cabai. Kombinasi ekstrak bawang putih dan tembakau sebesar 15\%:15\% dapat menekan hama hingga mortalitas 28,33\%. Semakin tinggi perbandingan konsentrasinya, semakin tinggi pula tingkat kematian hama. Pemberian ekstrak bawang putih dan tembakau secara tunggal pada konsentrasi $15 \%$ juga sudah mampu menekan hama hingga mortalitas 40\% dan 38, 67\% (Tigauw et al., 2015).

Tujuan dari pengabdian masyarakat ini, diharapkan masyarakat Desa Sikapat, kelompok tani wanita Sejahtera mampu membuat pestisida nabati dengan memanfaatkan tanaman di lingkungan sekitar untuk bahan pembuatan pestisida nabati seperti daun sirsak, daun pepaya dan juga bawang putih. Pestisida nabati yang dibuat dapat diaplikasikan pada tanaman milik kelompok tani sendiri sehingga dapat menurunkan biaya produksi. Selain itu pelatihan ini juga mempunyai potensi sebagai usaha kecil rumah tangga sehingga dapat menambah pendapatan.

\section{METODE} aplikasi.

Pelaksanaan yang dilakukan dibagi menjadi tiga tahapan yaitu penyuluhan, pelatihan dan a. Penyuluhan

Penyuluhan diberikan kepada kelompok tani wanita Sejahtera, dilakukan melalui penjelasan mengenai pengertian patogen dan hama, cara mencegah terjadinya penyakit dan serangan hama, serta diberikan pengetahuan mengenai manfaat dan keunggulan pestisida nabati. 
Selanjutnya dilakukan tanya jawab mengenai materi yang disampaikan sehingga peserta akan lebih paham. Melalui penyuluhan ini diharapkan peserta mengetahui dan memahami bahwa serangan hama dan penyakit tidak terjadi begitu saja. Selain itu juga dapat memanfaatkan tanaman di sekitar lingkungan tempat tinggal menjadi salah satu bahan pembuatan pestisida sehingga mampu menekan biaya produksi. Pestisida nabati relatif lebih mudah, murah untuk dibuat dan diaplikasikan jika dibandingkan dengan pestisida sintetik yang dijual di pasaran.

b. Pelatihan

Pelatihan dilakukan dengan mendemonstrasikan secara langsung cara pembuatan pestisida nabati dan dilakukan bersama dengan kelompok tani wanita Sejahtera. Bahan dan alat yang digunakan yaitu daun sirsak, daun pepaya, bawang putih, daun tembakau, detergen, blender, timbangan, baskom, gelas ukur, saringan, pisau, sendok atau pengaduk, botol dan sprayer.

Pestisida dari Daun Pepaya

1) Daun pepaya diambil sebanyak 100 gram

2) Daun dipotong-potong dan ditambah air sebanyak 100 gram

3) Selanjutnya daun ditumbuk atau diblender

4) Campuran tersebut disaring sampai terbentuk larutan stok dan dibiarkan semalaman.

5) Larutan stok kemudian diencerkan hingga $5 \%$ untuk aplikasi ke tanaman, misalnya $5 \mathrm{ml}$ larutan stok ditambahkan $95 \mathrm{ml}$ air.

Pestisida dari Bawang Putih

1) Tembakau direndam dengan 2 liter air panas selama 1 malam

2) Rendaman daun tembakau disaring untuk memisahkan ampasnya

3) Bawang putih diblender hingga halus dan disaring untuk mengambil airnya

4) Campurkan semua bahan dan aduk sampai rata

5) Larutan stok kemudian diencerkan hingga 10\% untuk aplikasi ke tanaman, misalnya 100 ml larutan stok pestisida ditambahkan $900 \mathrm{ml}$ air.

Pestisida dari daun Sirsak

1) Daun sirsak sebanyak 100 gram diambil

2) Daun ditumbuk atau dihaluskan menggunakan blender

3) Campuran tersebut disaring sampai terbentuk larutan stok dan dibiarkan semalaman.

4) Larutan stok kemudian diencerkan hingga $5 \%$ untuk aplikasi ke tanaman, misalnya $5 \mathrm{ml}$ larutan stok ditambahkan $95 \mathrm{ml}$ air.

c. Aplikasi

Aplikasi dilakukan pada tanaman hias yang ditanam oleh kelompok tani wanita Sejahtera di Desa Sikapat sehingga dapat diamati oleh peserta pelatihan sendiri, sehingga dapat dilihat keefektifannya.

\section{HASIL DAN PEMBAHASAN}

a. Penyuluhan

Sebelum penyuluhan dilakukan, tim pengabdian melengkapi surat perizinan dan kerjasama ke kantor kepala desa Sikapat dan juga ketua kelompok wanita tani Sejahtera. Penyuluhan dilakukan beberapa kali dengan materi berbeda tiap pertemuannya. Selama penyuluhan, peserta terlihat antusias mendengarkan dan melihat slide yang ditampilkan. Penyuluhan dilakukan dengan memberikan materi mengenai hama dan penyakit, manfaat pestisida nabati dari tanaman di sekitar lingkungan rumah, serta keunggulan pestisida nabati. Penyuluhan ini dapat meningkatkan pengetahuan mengenai pestisida nabati. 


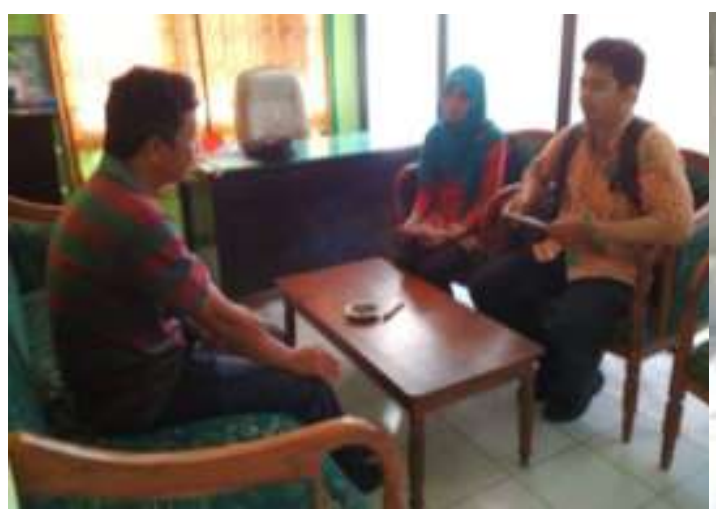

(a)

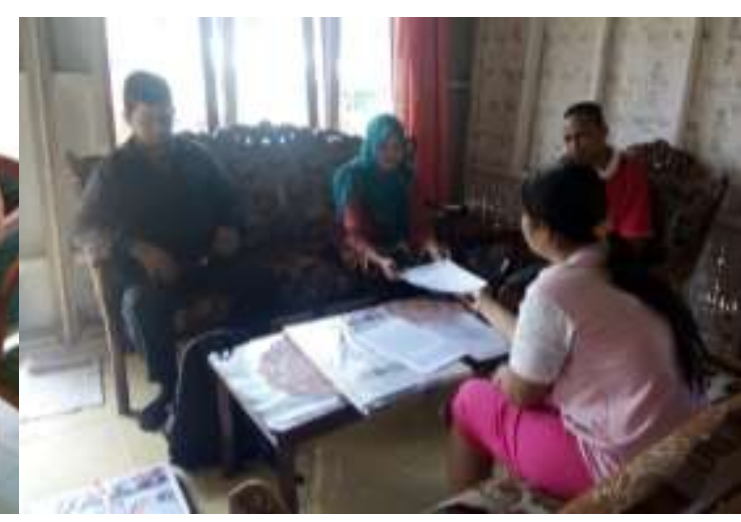

(b)

Gambar 1. Permohonan izin penyuluhan dan pelatihan pembuatan pestisida nabati ke kantor kepala desa Sikapat (a) dan ketua kelompok tani wanita Sejahtera (b)

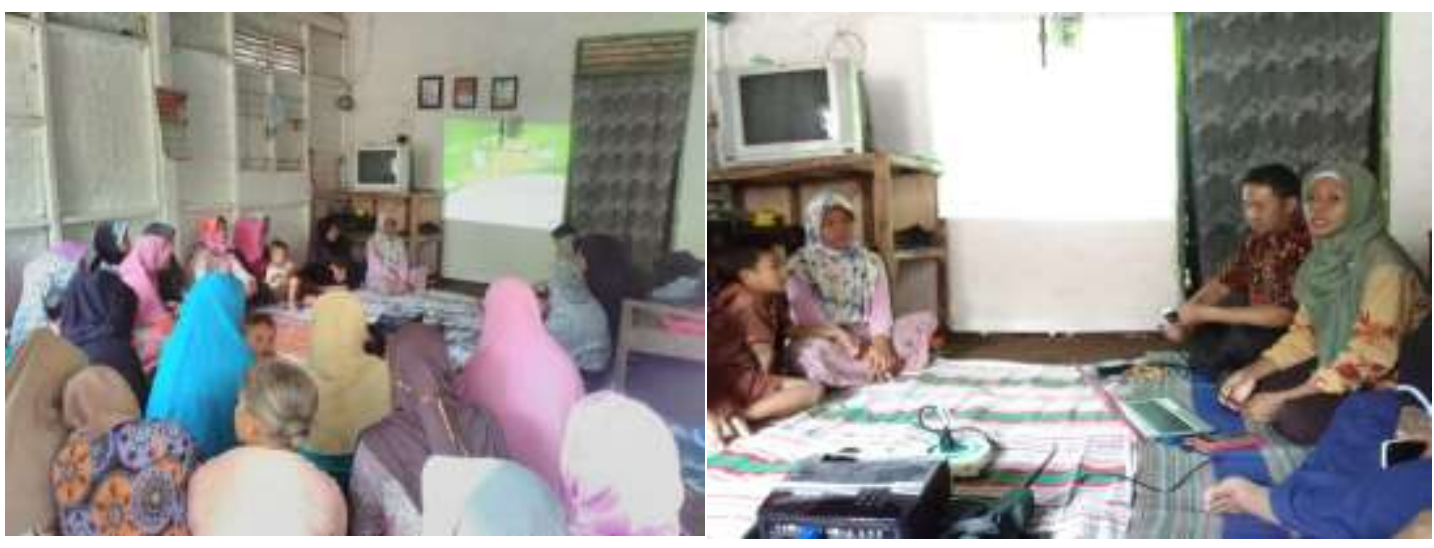

Gambar 2. Pemberian materi penyuluhan

\section{b. Pelatihan}

Pelatihan dilakukan dengan demonstrasi atau praktek langsung pembuatan pestisida nabati. Peserta pelatihan menyediakan sebagian bahan seperti daun sirsak, daun pepaya dan bawang putih serta diajak ikut serta mengikuti proses pembuatan pestisida seperti menimbang dan memotong bahan, menyaring dan juga menuang pestisida ke dalam botol. Aktifnya peserta mengikuti pelatihan diharapkan dapat membuat peserta paham dan dapat membuat pestisida secara mandiri. Tahapan pelatihan ini yaitu:

1. Persiapan bahan dan alat

- Bahan utama yang digunakan yaitu daun sirsak, daun pepaya, bawang putih, daun tembakau dan detergen.

- Alat yang digunakan yaitu blender, timbangan, baskom, gelas ukur, saringan, pisau, sendok atau pengaduk, botol, sprayer.

2. Proses pembuatan

- Daun pepaya (1 kg) dipotong-potong kecil menggunakan pisau, selanjutnya daun ditumbuk atau diblender dengan menambahkan air sebanyak 1 liter. Setelah itu, ditambahkan dengan detergen dan dimasukan ke dalam botol. Rendam selama satu malam. Larutan stok pestisida nabati daun pepaya siap diencerkan untuk aplikasi.

- Daun sirsak (1 kg) dipotong-potong kecil menggunakan pisau, selanjutnya daun ditumbuk atau diblender dengan menambahkan air sebanyak 1 liter. Setelah itu, ditambahkan dengan detergen dan dimasukan ke dalam botol. Rendam selama satu malam. Larutan stok pestisida nabati daun sirsak siap diencerkan untuk aplikasi. 
- Daun tembakau sebanyak 100 gram direndam dengan 2 liter air hangat. Setelah itu disaring. Bawang putih 100 gram dikupas, kemudian ditumbuk atau diblender, selanjutnya disaring. Campur air perasan bawang putih dengan larutan tembakau. Larutan stok dimasukkan ke dalam botol untuk disimpan. Selanjutnya dapat diencerkan sebelum digunakan.

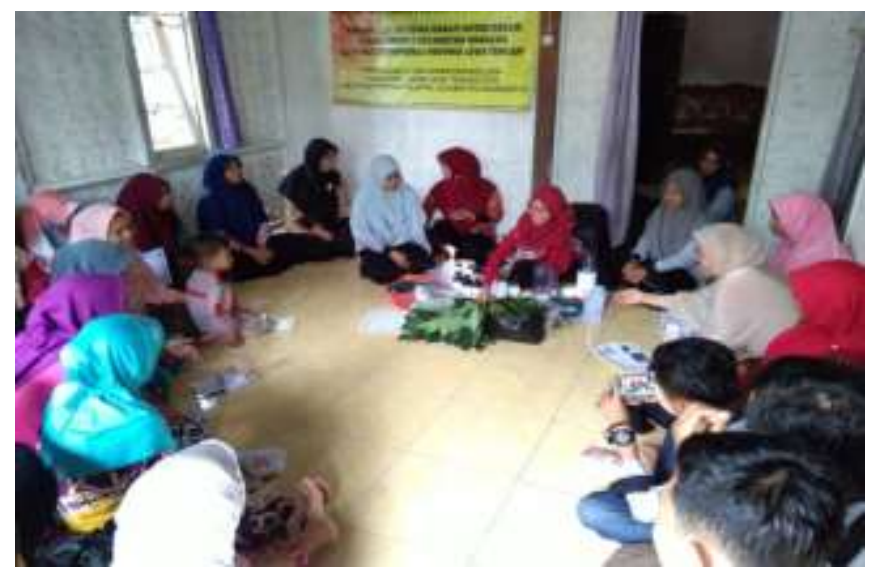

Gambar 3. Penjelasan pembuatan pestisida nabati

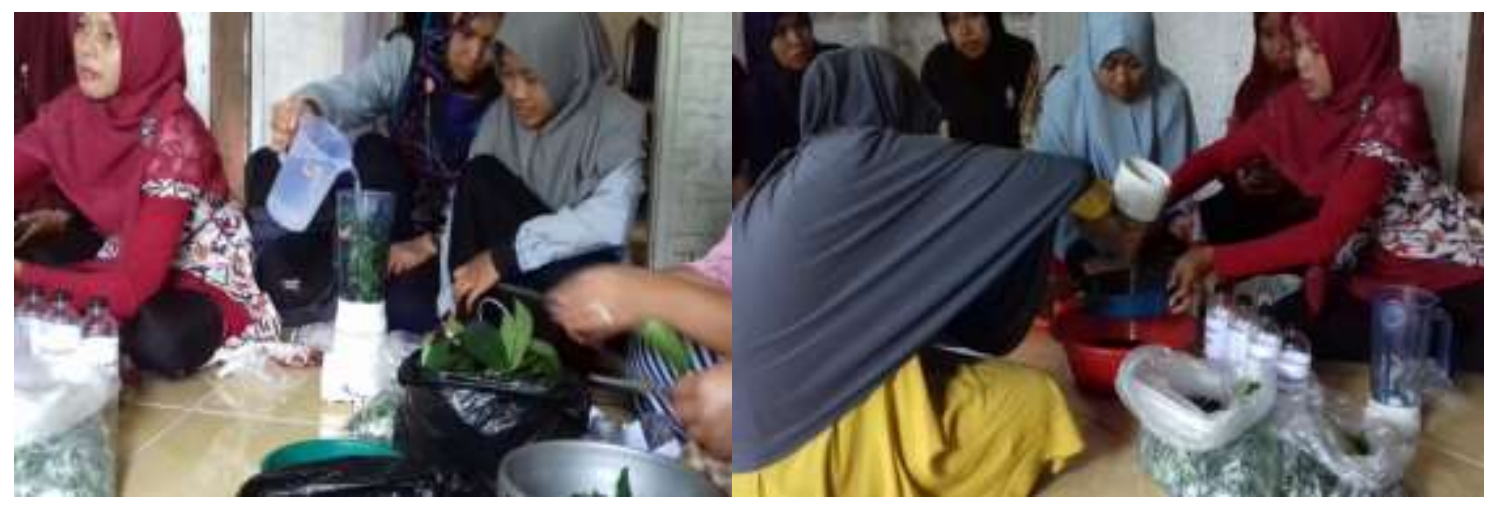

(a)

(b)

Gambar 4. Proses pembuatan pestisida nabati, bahan diblender (a) dan disaring (b)

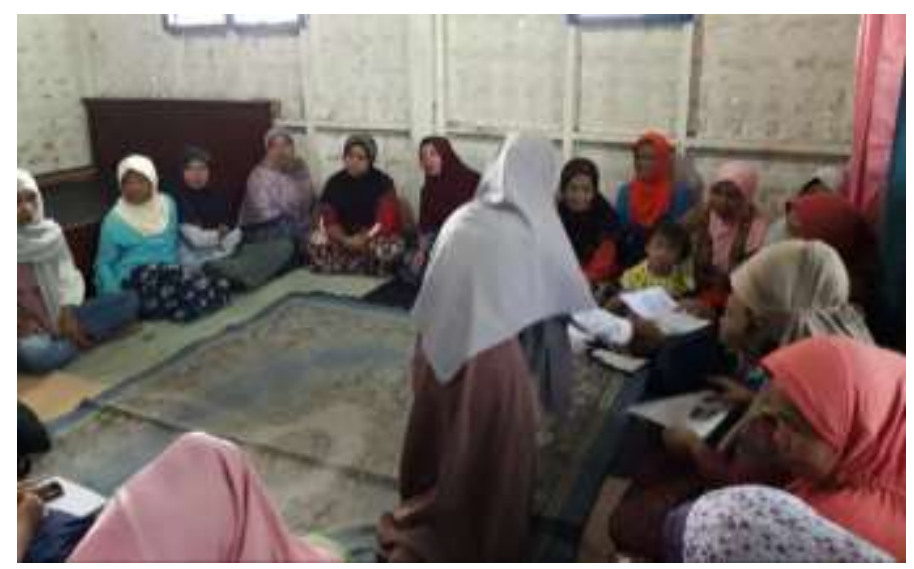

Gambar 5. Pembagian leafleat cara pembuatan pestisida nabati 


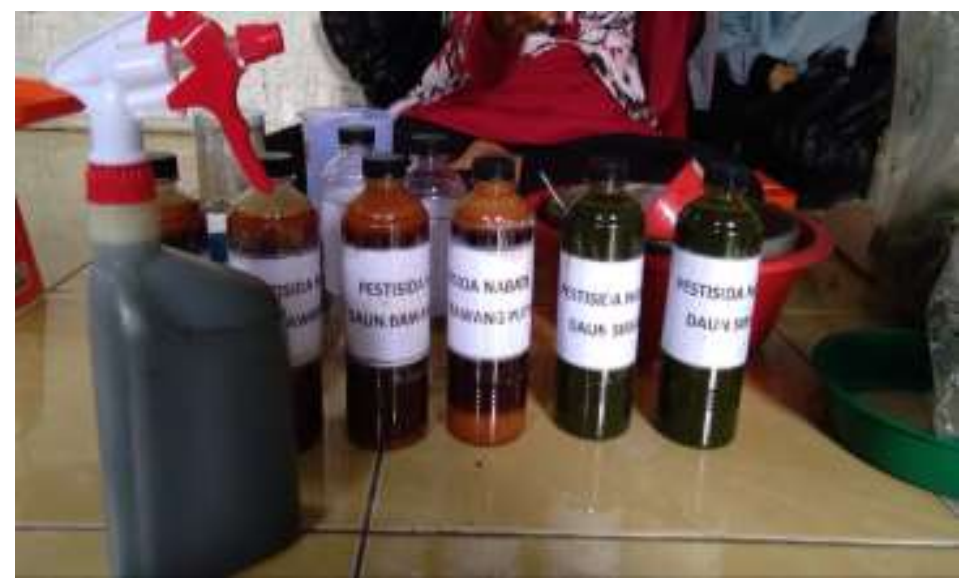

Gambar 6. Pestisida nabati cair yang sudah jadi

Setelah proses pembuatan pestisida selesai, tidak dapat langsung digunakan. Pestisida nabati cair yang sudah jadi harus didiamkan selama kurang lebih 24 jam sebelum digunakan. Penggunaan pestisida nabati cair dilakukan dengan menambahkan air sesuai kebutuhan sehingga mudah digunakan dan tidak memerlukan bahan yang sulit didapatkan.

\section{c. Aplikasi}

Aplikasi pestisida nabati cair dilakukan oleh peserta pelatihan sendiri dengan dosis yang sudah dijelaskan. Aplikasi pestisida sebaiknya dilakukan pada pagi hari atau sore hari. Pestisida disemprotkan ke tanaman menggunakan sprayer dilakukan sebelum matahari terlalu tinggi, supaya pestisida lebih efektif dan tidak cepat menguap. Apabila pagi hari dilakukan aplikasi, kemudian hujan turun, maka sebaiknya aplikasi dilakukan kembali pada sore hari.

Aplikasi pestisida nabati cair yang berasal dari daun pepaya dan daun sirsak, dilakukan dengan mengambil $50 \mathrm{ml}$ larutan stok pestisida nabati ditambah $100 \mathrm{ml}$ air untuk disemprotkan ke tanaman setiap 2-3 hari sekali. Jika serangan cukup parah, dosis dapat ditambah yaitu $100 \mathrm{ml}$ pestisida nabati cair dicampur dengan $100 \mathrm{ml}$ air. Sedangkan pestisida nabati berasal dari bawang putih dan daun tembakau, cukup $100 \mathrm{ml}$ larutan stok pestisida nabati cair ditambah dengan $100 \mathrm{ml}$ air. Aplikasi pada tanaman dan dosisnya bergantung pada tingkat serangan hama dan penyakit. Jika tingkat serangan cukup tinggi, maka dosis dapat ditingkatkan dan dilakukan lebih sering. Aplikasi dilakukan oleh kelompok tani wanita Sejahtera sendiri. Menurut anggota wanita tani, pemberian pestisida nabati yang diaplikasikan cukup membantu mengusir beberapa gangguan hama seperti kutu-kutuan yang sering menempel pada tanaman hias, selain itu juga mengurangi pengeluaran untuk pembelian pestisida sintetik.

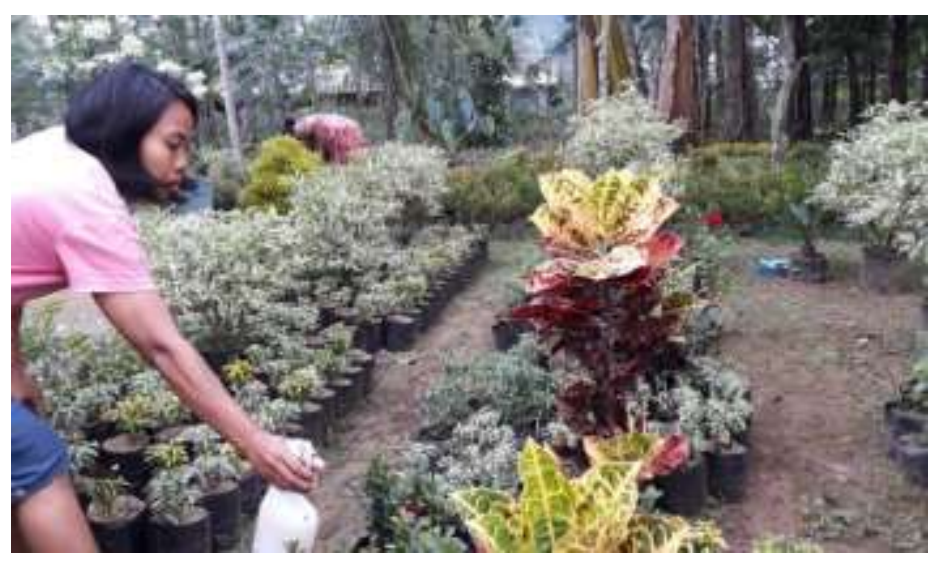

Gambar 7. Aplikasi pestisida nabati cair pada tanaman 


\section{KESIMPULAN}

Kesimpulan dari pelaksanaan kegiatan ini adalah sebagai berikut :

1. Kelompok tani wanita Sejahtera di Desa Sikapat Kecamatan Sumbang mempunyai semangat belajar dan antusiasme yang cukup tinggi dalam menerima materi penyuluhan.

2. Pembuatan pestisida nabati dapat dilakukan oleh peserta berdasarkan pengetahuan dan keterampilan yang telah diberikan dengan teknik yang lebih sederhana.

3. Tersedianya bahan di sekitar rumah peserta dan mudahnya pembuatan pestisida nabati dapat mengurangi penggunaan pestisida sintetik.

4. Masih perlu evaluasi serta program keberlanjutan pembuatan pestisida nabati dalam bidang kewirausahaan yang berpotensi meningkatkan kesejahteraan ekonomi.

\section{UCAPAN TERIMA KASIH}

Penulis mengucapkan terima kasih kepada Universitas Nahdlatul Ulama Purwokerto dan LPPM yang telah memberikan dukungan financial terhadap pengabdian kepada masyarakat ini.

\section{DAFTAR PUSTAKA}

Afidah, R., Yuliani, Tjipto, H., (2014). The Effect of Filtrate Combination of Dioscorea hispida, Annona muricata and Acalypha indica on the Mortality of Larvae of Order Lepidoptera. LenteraBio, 3(1), 45-49.

Arif, Adiba. (2015). Pengaruh Bahan Kimia terhadap Pestisida Lingkungan. JF FIK UINAM, 3(4), 134-143.

Bande, L.O.S., Andi, K.R., Saefuddin, Aceng, H., Laode, A., Mariadi, Vit, N.S. (2020). Pelatihan pembuatan pupuk hayari, agens hayati dan pestisida nabati Desa Aunupe Kabupaten Konawe Selatan. DINAMISIA, 4 (1), 195-200. DOI: https://doi.org/10.31849/dinamisia.v4i1.3512

Corsini, E., Sokooti, M., Galli, C.L., Moretto, A., Collosio, C. (2012). Pesticide induced immunotoxicity in humans: A comprehensive review of the existing evidence. Toxicology, (307) 123- 135.

Deden. (2017). Efektifitas Pestisida Nabati Terhadap Pengendalian Ulat Grayak (Spodoptera sp.) pada Tanaman Sawi (Brassica sinensis L.). Jurnal Logika, 19(1), 7-11.

Gilden, R.C., Huffling, K., Sattler, B., (2010). Pesticides and health risks. J. Obstet. Gynecol. Neonat. Nurs, 39, 103-110.

Hartini, F., Yahdi. (2015). Potensi Ekstrak Daun Sirsak (Annona muricata L.) sebagai Insektisida Kutu Daun Persik (Myzus persicae Sulz) pada Daun Tanaman Cabai Rawit (Capsicum frutescens). BIOTA, 107-116.

Lebang, M.S., Dantje, T., Jimmy, R. (2016). Efektifitas Daun Sirsak (Anona muricata L) dan Daun Gamal (Gliricidia sepium) dalam Pengendalian Hama Walang Sangit (Leptocorisa acuta T) pada Tanaman Padi. Jurnal Bioslogos, 6(2), 51-58.

Romadhona, R., Djamilah, Mukhtasar. (2018). Efektivitas ekstrak daun pepaya dalam pengendalian kutu daun pada fase vegetatif tanaman terung. Jurnal Ilmu-Ilmu Pertanian Indonesia, 20(1), 1-7.

Setiawan, H., Oka, A.A. (2015). Pengaruh Variasi Dosis Larutan Daun Pepaya (Carica papaya L.) terhadap Mortalitas Hama Kutu Daun (Aphis craccivora) pada Tanaman Kacang Panjang (Vigna sinensis L.) Sebagai Sumber Belajar Biologi. Biedukasi, 6(1), 54-62.

Supriyono. (2016). Potensi Ekstrak Bawang Putih Sebagai Fungisida Nabati terhadap Jamur Sclerotium rolfsii Sacc. Prosiding Konser Karya Ilmiah, 2, 17-22. 
Tigauw, S.M.I., Christina, L.S., Jusuf, M. (2015). Efektivitas ekstrak bawang putih dan tembakau terhadapa kutu daun (Myzus persicae Sulz) pada tanaman cabai (Capsicum sp.). Eugenia, 21(3), 135-141.

Yulianty, Lande, M.L., Handayani, T.T. (2018). Efektifitas Ekstrak Daun Pepaya (Carica papaya L.) untuk Mengendalikan Penyakit Antraknosa yang disebabkan oleh Jamur Colletotrichum sp. pada Cabai (Capsicum annuum L.). Jurnal Mikologi Indonesia, 2(1), 49-55. 